\title{
粉末成形・加工による特異組織構造形成と高次機能化 PM Materials with Unique Microstructures and their Multi-Functionalization
}

\author{
近藤 勝義 \\ Katsuyoshi KONDOH \\ 大阪大学 \\ Osaka University
}

本特集では，金属積層造形プロセスやナノ粒子を用いた低 温固相接合プロセスによる組織構造制御や材料の高機能化, また粉末冶金と塑性加工の融合によるへテロ組織構造形成に よる特異な力学特性の発現, 炭素系ナノ材料を第二相とした 金属基複合材料の物性解析，固溶現象と強化機構に関する実 験解析および理論計算など，粉末成形・加工の観点から金 属・非金属材料における組織構造制御と各種物性の関係につ いて幅広い分野での研究成果に係る講演発表を募集し，100 名を超える多くの参加者が聴講する中で活発な議論のもと本 特集の企画・運営を行いました。本特集に関して，2 件の特 別講演， 1 件の招待講演を含めて合計 12 件の講演発表を $3 つ$ のセッションに分けて行いました.

最初のセッションにおいて, 特別講演では, 金属積層造形 プロセスを基調とした各種金属材料における特異な組織構造 形成機構の解明と高次機能化に関する講演を中心に, プロセ スパラメータが積層造形体の組織形成に及ぼす影響を実験解 析および数值計算により明らかにした上で，組織構造制御に よる造形体の力学応答性に関する制御性に関して詳細な報告 が行われました。また，招待講演では Al-Si 系積層造形体へ の熱処理による組織制御と力学特性 (強化機構と変形挙動) の関係について, 微視的組織構造解析を通じて得られた研究 結果について発表が行われました.
第 2 セッションでは, 特別講演として粉末表面をナノ構 造化したマイクロスケールの Ag 粉末による低温焼結および dealloying プロセスを利用したナノポーラス構造 Ag シート を用いた固相接合法に関する講演が行われました。また一般 講演として，燃焼合成法による Al-Ti ポーラス体の発砲過程 に関するX線その場観察とその過程における反応合成・組 織形成機構の理解を通じて多孔質構造化メカニズムに関する 研究結果が報告されました。他方，銅やアルミニウムにカー ボン系材料を分散した複合材料における熱伝導性に及ぼす カーボン材の配向性や元素種の影響を実験解析および数值計 算により詳細に検討した結果に関して発表が行われました.

第 3 セッションにおいて, チタンやアルミニウムの組織構 造に着目し, 結晶粒の粗微複相化構造の形成による高強度・ 高延性の同時発現，その場合成法を用いた TiAl 金属間化合 物への $\mathrm{Al}_{2} \mathrm{O}_{3}$ 粒子分散による強化メカニズムの解明，急冷凝 固 $\mathrm{Al}-\mathrm{Fe}$ 合金粉末を用いたバルク体における分散相による強 度・延性と電気伝導性のバランスの実現， $\beta$-Ti 合金におけ る酸素原子固溶挙動の実験解析・理論計算による解明および 強化機構の解明, Ti-Fe-Zr 系焼結合金の針状組織形成機構と 強度向上機構の定量的解析などに関する 5 件の発表講演を通 じて，活発な質疑応答が行われました。 